\title{
Pengaruh Kecukupan Modal, Penyaluran Kredit dan Ukuran Perusahaan Pada Profitabilitas Dengan Risiko Kredit Sebagai Pemoderasi
}

\author{
A.A Trisha Dewi Parasthiwi ${ }^{1}$ \\ I Gusti Ayu Nyoman Budiasih ${ }^{2}$ \\ ${ }^{1,2}$ Fakultas Ekonomi dan Bisnis Universitas Udayana (Unud), Bali, Indonesia \\ e-mail:trishadewi12@yahoo.co.id
}

\begin{abstract}
ABSTRAK
Penelitian ini dilakukan pada perusahaan perbankan yang terdaftar di Bursa Efek Indonesia periode 2013-2017 yaitu sebanyak 42 perusahaan. Teknik pengambilan sampel dalam penelitian ini diambil berdasarkan metode non probability sampling dengan teknik purposive sampling sehingga menghasilkan sampel sebanyak 32 perusahaan. Teknik analisis data yang digunakan dalam penelitian ini adalah uji moderated regression analysis. Berdasarkan hasil analisis ditemukan bahwa kecukupan modal berpengaruh positif pada profitabilitas, penyaluran kredit berpengaruh positif pada profitabilitas dan ukuran perusahaan berpengaruh positif pada profitabilitas. Hasil penelitian ini juga menunjukkan risiko kredit tidak mampu memperlemah pengaruh kecukupan modal dan penyaluran kredit pada profitabilitas dan risiko kredit mampu memperlemah pengaruh ukuran perusahaan pada profitabilitas.

Kata Kunci:kecukupan modal, penyaluran kredit, ukuran perusahaan, risiko kredit, profitabilitas.
\end{abstract}

\begin{abstract}
This research was conducted at banking companies listed on the Indonesia Stock Exchange in the period 2013-2017, which were 42 companies. The sampling technique in this study was taken based on non probability sampling method with purposive sampling technique so as to produce a sample of 32 companies. The data analysis technique used in this study was moderated regression analysis. Based on the results of the analysis it was found that capital adequacy has a positive effect on profitability, credit distribution has a positive effect on profitability and firm size has a positive effect on profitability. The results of this study also show that credit risk is not able to weaken the influence of capital adequacy and lending to profitability and credit risk is able to weaken the influence of company size on profitability.

Keywords: capital adequacy, credit distribution, company size, credit risk, profitability
\end{abstract}

\section{PENDAHULUAN}

Perusahaan dalam menjalankan kegiatan operasionalnya, memiliki salah satu tujuan utama yaitu memperoleh keuntungan atau mencapai tingkat profitabilitas yang maksimal agar mampu memperoleh kepercayaan dari masyarakat maupun investor. Pengaruh dari faktor kepercayaan para nasabah pada perusahaan perbankan akan sangat berdampak pada kemajuan perkembangan perusahaan 
A.A. Trisha Dewi Parashtiwi dan I Gusti Ayu Nyoman Budiasih. Pengaruh...

serta meningkatkan mutu dan kualitas dari perusahaan itu sendiri (Shamsuddoha, Mohammad and Alamgir, 2004). Peningkatan mutu dan kualitas perusahaan perbankan dipengaruhi oleh adanya kinerja suatu bank yang sehat, dimana ini sangat diperlukan untuk kelancaran fungsi bank sebagai penyalur dana dari pihak debitur kepada pihak kreditur.

Profitabilitas merupakan kemampuan perusahaan dalam menghasilkan laba pada periode tertentu. Profitabilitas juga memiliki arti penting bagibadan usaha guna untuk mempertahankan kelangsungan hidupnya dalam jangka panjang, karena profitabilitas itu menunjukkan seberapa penting badan usaha tersebut mempunyai prospek yang baik di masa yang akan datang (Haneef et al., 2012). Profitabilitas juga merupakan rasio untuk mengukur kinerja keuangan perusahaan guna mencari keuntungan pada periode tertentu (Kasmir, 2012:114). Pentingnya meneliti profitabilitas yakni dengan adanya keuntungan yang diperoleh maka perusahaan dapat mengelola aktivitas perusahaan sehingga penting bagi perusahaan untuk mengelola atau menjaga profitabilitas untuk melakukan ekspansi usaha. Jika perusahaan memiliki tingkat profitabilitas yang tinggi maka perusahaan tersebut memiliki dua pilihan dimana perusahaan bisa membagikan dividen kepada pemegang saham atau memilih digunakan untuk ekspansi usaha. Salah satu rasio yang dapat digunakan untuk mengukur profitabilitas adalah Return On Asset (ROA).

Bank Umum dan Bank Perkreditan Rakyat (BPR) merupakan dua jenis bank yang terdapat di Negara Indonesia. Bank Umum dapat dibedakan menjadi dua yaitu Bank Umum Konvensional (BUK) dan Bank Umum Syariah (BUS). 
Penelitian ini dilakukan pada perusahaan perbankan khususnya pada bank umum konvensional. Bank umum konvensional adalah bank yang memiliki aktivitas menerima dana masyarakat dengan memberikan bunga sebagai bentuk balas jasanya. Dibawah ini terdapat Tabel 1 yang memperlihatkan tingkat ROA pada bank umum konvensional dari tahun 2013 sampai 2017:

Tabel 1.

Return On Asset Bank Umum Konvensional Tahun 2013 s/d 2017

\begin{tabular}{ll}
\hline Tahun & Return On Asset (\%) \\
\hline 2013 & 3,08 \\
2014 & 2,85 \\
2015 & 2,32 \\
2016 & 2,23 \\
2017 & 2,49 \\
\hline
\end{tabular}

Sumber: Statistik Perbankan Indonesia, 2018

Pada Tabel 1 menunjukkan bahwa ROA pada bank umum konvensional tahun 2013 sampai tahun 2016 mengalami penurunan kecuali pada tahun 2017 mengalami peningkatan. ROA terendah terjadi pada tahun 2016 yaitu sebesar 2,23 persen dan ROA tertinggi terjadi pada tahun 2013 yaitu sebesar 3,08 persen. Hal ini menunjukan bahwa bank umum konvensional cenderung masih mengalami kesulitan untuk menjaga pertumbuhan ROA setiap tahunnya. Tingkat ROA yang rendah dapat dipengaruhi oleh adanya beberapa faktor, dimana faktor tersebut juga dapat digunakan dalam penilaian kinerja bank yang pertama yaitu kecukupan modal (Hendra, 2016). Terdapat faktor lain yang mempengaruhi tingkat ROA selain kecukupan modal yaitu faktor aktivitas penyaluran kredit (Trisna, 2017). Purba (2018) menyatakan bahwa selain rasio keuangan terdapat faktor lain yang mempengaruhi tingkat ROA yaitu ukuran perusahaan.

Trade off theory mengasumsikan bahwa struktur modal perusahaan merupakan hasil trade off dari keuntungan pajak dengan menggunakan hutang dan 
A.A. Trisha Dewi Parashtiwi dan I Gusti Ayu Nyoman Budiasih. Pengaruh...

biaya yang akan timbul sebagai akibat penggunaan hutang tersebut. Apabila manfaat yang diterima masih lebih besar dibandingkan pengorbanan, maka perusahaan akan menambah jumlah utang yang dimiliki perusahaan. Sebaliknya apabila pengorbanan dalam menggunakan hutang lebih besar daripada manfaat yang diterima, maka perusahaan tidak menambah jumlah hutang yang akan dimiliki perusahaan. Berdasarkan teori ini, perusahaan berusaha mempertahankan struktur modal yang ditargetkan dengan tujuan memaksimumkan profitabilitas bank.

Faktor penting agar suatu perusahaan dapat beroperasi adalah memiliki kecukupan modal guna membiayai kegiatan operasional perusahaan. Modal merupakan salah satu faktor yang berperan penting terhadap kinerja suatu perusahaan. Modal yang dimiliki oleh bank berfungsi untuk menanggung risiko dan kerugiannya yang dialami oleh bank, sehingga bank dituntut memiliki modal yang cukup dalam artian mampu untuk menanggung risiko dan kerugian tersebut. Kecukupan modal perusahaan perbankan dapat dilihat dari angka Capital Adequacy Ratio (CAR). CAR merupakan rasio permodalan untuk melihat bagaimana kemampuan bank dalam menyediakan dana guna untuk keperluan pengembangan usaha dan menampung risiko kerugian dana yang diakibatkan oleh kegiatan operasional bank (Ali, 2004:132). Jika rasio CAR tinggi maka bank dinilai mampu meminimalisir adanya risiko yang timbul akibat kegiatan operasionalnya, sehingga profitabilitas akan meningkat.

Selain kecukupan modal, profitabilitas juga dapat dipengaruhi oleh adanya aktivitas penyaluran kredit. Aktivitas dari penyaluran kredit merupakan 
keuntungan bagi bank yang berasal dari pendapatan bunga. Semakin sering bank menyalurkan kreditnya maka pendapatan bunga bank akan semakin bertambah, sehingga akan berdampak pada peningkatan profitabilitas. Bank akan memberikan kredit ke nasabah jika ia mampu mengembalikan pinjaman yang diterimanya sesuai dengan jangka waktu dan syarat-syarat yang sudah ditetapkan. Penyaluran kredit yang dilakukan oleh bank dapat dilihat melalui Loan to Deposit Ratio $(L D R)$. Besarnya LDR akan berpengaruh terhadap laba melalui penciptaan kredit. Salah satu indikator yang menunjukkan tingkat ekspansi kredit juga dapat dilihat dari rasio LDR sehingga LDR dapat digunakan untuk mengukur berjalan tidaknya suatu kegiatan intermediasi bank yang salah satunya adalah menyalurkan dana berupa kredit. LDR menunjukkan tingkat kemampuan bank dalam menyalurkan dana pihak ketiga yang dihimpun bank (Utami, 2016).

Selain rasio keuangan, terdapat juga variabel lain yang dapat mempengaruhi profitabilitas salah satunya adalah ukuran perusahaan. Ukuran perusahaan dapat dinyatakan dengan total aktiva, penjualan dan kapitalisasi pasar (Sartono, 2014:248). Ukuran perusahaan dalam penelitian ini dilihat berdasarkan besarnya total aktiva yang dimiliki perusahaan. Aktiva merupakan suatu komponen penting dari suatu perusahaan (Ratnawati et al., 2013). Menurut Kosmidou (2008), bank yang lebih besar ukuran asetnya lebih menguntungkan daripada bank yang ukuran asetnya kecil karena ukuran bank yang lebih besar mempunyai tingkat efisiensi yang lebih tinggi. Perusahaan besar dengan aset yang lebih besar serta perusahaan tersebut sudah dikatakan mapan maka akan lebih mudah memperoleh modal di pasar modal. Ukuran perusahaan yang besar juga 
A.A. Trisha Dewi Parashtiwi dan I Gusti Ayu Nyoman Budiasih. Pengaruh...

dapat mengindikasikan bahwa perusahaan mempunyai komitmen yang tinggi untuk terus memperbaiki kinerjanya, sehingga pasar akan mau membayar lebih mahal karena percaya akan mendapatkan pengembalian yang menguntungkan dari perusahaan tersebut.

Penelitian mengenai kecukupan modal, penyaluran kredit dan ukuran perusahaan pada profitabilitas telah diteliti oleh beberapa peneliti sebelumnya. Hendra (2016) menyatakan bahwa kecukupan modal berpengaruh positif pada profitabilitas. Berbeda dengan penelitian yang di lakukan oleh Wantera (2015) yang menyatakan bahwa kecukupan modal mempengaruhi profitabilitas secara negatif. Penelitian yang di lakukan oleh Indrayani dkk. (2016) dan Madjid (2013) juga mengatakan bahwa jumlah kredit yang disalurkan diproksikan dengan Loan to Deposit Ratio $(L D R)$ berpengaruh positif pada profitabilitas. Akan tetapi, penelitian tersebut bertolak belakang dengan penelitian (Wibisono, 2013) yang menunjukkan hasil bahwa Loan to Deposit Ratio (LDR) berpengaruh negatif pada profitabilitas. Adawiyah (2017), menyatakan ukuran perusahaan berpengaruh positif pada profitabilitas. Sedangkan menurut Prasanjaya (2013), ukuran perusahaan berpengaruh negatif signifikan pada profitabilitas perusahaan.

Berdasarkan hasil penelitian sebelumnya, terdapat ketidakonsistenan hasil mengenai pengaruh kecukupan modal, penyaluran kredit dan ukuran perusahaan pada profitabilitas. Perbedaan hasil penelitian tersebut dapat terjadi karena adanya beberapa faktor internal dan eksternal yang mempengaruhi kecukupan modal, penyaluran kredit dan ukuran perusahaan. Salah satu faktor internal yang dapat mempengaruhi kecukupan modal, tingkat penyaluran kredit dan ukuran 
perusahaan adalah risiko kredit (Novita, 2016). Alasannya risiko kredit dipilih menjadi variabel moderasi karena fungsi utama bank yakni menyalurkan kredit, karena dalam menyalurkan kredit tentunya bank tidak akan terlepas dari adanya risiko kredit yang muncul sehingga dapat diduga jika risiko kredit yang tinggi akan berdampak pada kecukupan modal, penyaluran kredit dan ukuran perusahaan sehingga profitabilitas bank akan menurun. Berdasarkan hal tersebut maka perlu diteliti kembali dengan menambahkan variabel moderasi yaitu risko kredit yang diduga mampu memperkuat atau memperlemah hubungan antara variabel tersebut.

Kegiatan pemberian kredit yang dilakukan oleh bank mengandung risiko tidak lancarnya pembayaran kredit atau kredit bermasalah yang dalam istilah perbankan dikenal dengan rasio Non Performing Loan (NPL). NPL didefinisikan sebagai pinjaman yang mengalami kesulitan pelunasan dari pihak debitur atau sering disebut kredit macet pada bank (Riyadi, 2006:161). Kredit bermasalah meningkat karena kurangnya manajemen risiko, sehingga mengancam profitabilitas bank (Haneef et al., 2012). Inflasi, nilai tukar dan suku bunga juga faktor yang mempengaruhi kredit bermasalah pada sektor perbankan (Farhan, 2012). Jika risiko kredit tinggi, maka pengelolaan atas kredit tersebut dinilai kurang baik, sehingga akan berdampak pada penurunan profitabilitas. Bank harus mampu meminimalkan rasio NPL karena rasio NPL berdampak pada kinerja bank tersebut. Hal ini didukung dengan penelitian Suardita (2015) yang menyatakan bahwa kurangnya tindakan manajemen atas risiko kredit bermasalah yang meningkat akan mampu menurunkan aktivitas dari penyaluran kredit maupun 
A.A. Trisha Dewi Parashtiwi dan I Gusti Ayu Nyoman Budiasih. Pengaruh...

kecukupan modal. Penelitian tersebut juga didukung oleh Purba (2018) juga menemukan bahwa risiko kredit merupakan risiko yang serius karena dapat mendatangkan kerugian yang berdampak pada ukuran perusahaan dan penyaluran kredit pada profitabilitas. Berdasarkan uraian di atas dapat dikatakan bahwa risiko kredit dapat memperlemah dalam kemampuan bank untuk memperoleh modal yang cukup, pendapatan bunga yang berasal dari penyaluran kredit serta kehilangan investor yang merupakan sumber modal bagi perusahaan tersebut. Tingginya risiko kredit ini diduga dapat memperlemah kemampuan dalam memoderasikecukupan modal, penyaluran kredit dan ukuran perusahaan pada profitabilitas perusahaan.

Terdapat contoh kasus perbankan yang profitabilitasnya menurun akibat adanya tingkat kredit yang bermasalah. Berdasarkan Laporan Keuangan Tahunan PT Bank Century, Tbk. Tahun 2008, jumlah NPL yang dimiliki Bank Century mencapai 10,42 persen, sehingga mencatat kerugian sebesar Rp. 7,28 triliun, dan ROA sebesar $-52,09$ persen yang berdampak pada kebangkrutan Bank Century.Penurunan ROA ini disebabkan karena lambatnya pertumbuhan kredit ditambah dengan meningkatnya NPL. NPL yang meningkat, mengharuskan bank mengeluarkan biaya cadangan kerugian yang lebih banyak. Bank yang berhasil mampu menunjukkan bahwa bank dapat mengelola kreditnya dengan baik, sedangkan bank yang tidak dapat mengelola kreditnya akan berdampak pada kemunduran usaha bank tersebut (Purba, 2018).

Perusahaan perbankan dipilih sebagai lokasi pada penelitian ini karena perkembangan kinerja keuangan perbankan yang terdaftar di BEI dapat menjadi 
pilihan investasi yang baik dan menjanjikan bagi para calon investor untuk meningkatkan kesejahteraanya, sehingga perlu dilakukan analisis terhadap kinerja terutama dalam kemampuannya menghasilkan keuntungan. Selain itu, perusahaan perbankan mampu menunjang perekonomian Indonesia secara menyeluruh baik dalam memberikan jasa kredit pinjaman untuk usaha mikro dan makro dan juga sebagai media penyimpanan dana yang aman bagi nasabahnya.

Hasil penelitian yang dilakukan oleh Primadewi (2015) menyatakan bahwa kecukupan modal berpengaruh positif pada profitabilitas BPD Bali. Akhtar et al. (2011) menyatakan bahwa Capital Adequacy Ratio (CAR) berpengaruh positif pada profitabilitas Islamic Banks of Pakistan. Singh (2015) menyatakan bahwa kecukupan modal berpengaruh positif pada profitabilitas perusahaan perbankan di India. Hendra (2016) juga menyatakan bahwa kecukupan modal yang dimiliki bank berpengaruh positif pada profitabilitas perbankan.

Kecukupan modal yang memadai akan berdampak pada profitabilitas perusahaan yang akan meningkat karena perusahaan dapat melakukan kegiatan operasionalnya tanpa perlu khawatir dengan risiko yang ditimbulkan. Markusiwati (2007) dalam penelitiannya menyatakan bahwa semakin tinggi presentase CAR akan mempengaruhi tingkat profitabilitas menjadi tinggi pula sehingga dapat menjadi tolak ukur bagi investor dan pihak lain yang berkepentingan untuk melihat apakah bank tersebut sehat atau tidak. Tingginya CAR juga dapat menambah kepercayaan masyarakat terhadap bank, karena jaminan kepercayaan terhadap masyarakat semakin tinggi. Semakin tinggi nilai CAR bank, akan menunjukkan bank tersebut semakin sehat. Selain itu, semakin tinggi permodalan 
A.A. Trisha Dewi Parashtiwi dan I Gusti Ayu Nyoman Budiasih. Pengaruh...

bank maka semakin tinggi kemampuan permodalan bank dalam menjaga kemungkinan timbulnya risiko kerugian kegiatan usahanya sehingga kinerja bank juga meningkat. Berdasarkan uraian tersebut, maka dapat dirumuskan hipotesis sebagai berikut:

$\mathrm{H}_{1}$ : Kecukupan modal berpengaruh positif pada profitabilitas.

Penelitian yang dilakukan oleh Rengasamy (2014) menyatakan bahwa penyaluran kredit berpengaruh positif pada profitabilitas Commercials Bank in Malaysia. Hariputri (2018) menyatakan bahwa penyaluran kredit berpengaruh pada profitabilitas LPD Denpasar. Farida (2015) dan Agustiningrum (2013) menyatakan bahwa penyaluran kredit berpengaruh positif pada profitabilitas perbanakan yang go public di Bursa Efek Indonesia.

Semakin besar jumlah kredit yang disalurkan kepada nasabah maka jumlah dana yang menganggur akan semakin berkurang dan pendapatan bunga yang diperoleh semakin meningkat. Semakin tinggi rasio LDR yang diberikan maka profitabilitas perbankan akan semakin tinggi (Setiadi, 2010). Berdasarkan uraian tersebut, maka dapat dirumuskan hipotesis sebagai berikut:

$\mathrm{H}_{2}$ : Penyaluran kredit berpengaruh positif pada profitabilitas.

Penelitian yang dilakukan oleh Hariyanto (2014) menyatakan bahwa ukuran perusahaan berpengaruh positif pada profitabilitas sektor keuangan. Velnampy (2010) menyatakan bahwa ukuran perusahaan berpengaruh positif pada profitabilitas perusahaan manufaktur. Koriawan (2014) menyatakan bahwa ukuran perusahaan berpengaruh pada profitabilitas LPD di Kabupaten Buleleng. Mario 
(2015) menyatakan bahwa ukuran perusahaan berpengaruh positif pada profitabilitas perbankan.

Suatu perusahaan besar dan mapan akan mudah untuk masuk ke pasar modal. Karena kemudahan untuk berhubungan dengan pasar modal maka berarti fleksibilitas lebih besar dan tingkat kepercayaan investor juga lebih besar karena mempunyai kinerja operasional yang lebih besar. Perusahaan besar mampu menarik minat investor yang lebih besar dibandingkan dengan perusahaan kecil, karena mempunyai fleksibilitas penempatan investasi yang lebih baik. Berdasarkan uraian tersebut, maka dapat dirumuskan hipotesis sebagai berikut:

$\mathrm{H}_{3}$ : Ukuran perusahaan berpengaruh positif pada profitabilitas.

Penelitian yang dilakukan oleh Suardita (2015) menunjukkan bahwa risiko kredit memperlemah pengaruh kecukupan modal pada profitabilitas perusahaan perbankan. Yunita (2016) yang menunjukkan bahwa risiko kredit memperlemah pengaruh kecukupan modal pada profitabilitas Bank Pembangunan Daerah Sumatra Barat. Warnayanti (2018) juga menyatakan risiko kredit memperlemah pengaruh kecukupan modal pada profitabilitas perbankan.

Tingginya rasio NPL disebabkan oleh adanya peningkatan kredit bermasalah terhadap total kredit yang dimiliki oleh bank. Hal tersebut mengakibatkan pendapatan bunga bank akan menurun sehingga profitabilitas bank akan mengalami penurunan, ini akan berdampak juga pada modal bank menurun dan CAR akan semakin rendah. Berdasarkan uraian tersebut, maka dapat dirumuskan hipotesis sebagai berikut:

$\mathrm{H}_{4}$ : Risiko kredit memperlemah pengaruh kecukupan modal pada profitabilitas perusahaan. 
A.A. Trisha Dewi Parashtiwi dan I Gusti Ayu Nyoman Budiasih. Pengaruh...

Penelitian dilakukan oleh Novita (2016) yang menyatakan bahwa risiko kredit memperlemah pengaruh penyaluran kredit pada profitabilitas LPD di Kabupaten Tabanan. Oktaviani dan Yusuf (2014) yang menyatakan bahwa risiko kredit memperlemah pengaruh penyaluran kredit pada profitabilitas bank umum.

Berdasarkan hasil riset diatas bahwa semakin besar NPL akan membuat bank perlahan mengurangi jumlah penyaluran kreditnya. Semakin banyak kredit yang disalurkan, maka semakin besar risiko kredit yang dihadapi oleh perbankan maka akan berdampak terhadap profitabilitas. Berdasarkan uraian diatas maka dapat dirumuskan hipotesis sebagai berikut:

$\mathrm{H}_{5}$ : Risiko kredit meperlemah pengaruh penyaluran kredit pada profitabilitas.

Penelitian yang dilakukan oleh Purba (2018) yang menyatakan bahwa risiko kredit memperlemah pengaruh ukuran perusahaan pada profitabilitas perbankan. Fanani dan Alvaribi (2013) juga menyatakan bahwa risiko kredit memperlemah pengaruh ukuran perusahaan pada profitabilitas perbankan. Kumala (2015) menyatakan bahwa ukuran perusahaan berpengaruh negatif pada risiko kredit perusahaan perbankan.

Investor yang mempertimbangkan risiko kredit sebagai salah satu faktor dalam berinvestasi, maka hal ini dapat memperlemah pengaruh ukuran perusahaan pada profitabilitas perusahaan. Perusahaan yang memiliki aset yang tinggi, namun memiliki risiko kredit yang tinggi pula dapat menyebabkan investor akan lebih berhati-hati dalam mengivestasikan dananya sehingga berdampak pada penurunan profitabilitas. Berdasarkan uraian diatas maka dapat dirumuskan hipotesis sebagai berikut: 
$\mathrm{H}_{6}$ : Risiko kredit memperlemah pengaruh ukuran perusahaan pada profitabilitas.

\section{METODE PENELITIAN}

Penelitian ini dilakukan pada perusahaan perbankan yang terdaftar di Bursa Efek Indonesia (BEI) periode 2013-2017 yang dapat diakses melalui situs resmi Bursa Efek Indonesia (BEI) yaitu www.idx.co.id maupun website lainnya yang terkait.Data yang didapatkan berupa laporan keuangan tahunan perusahaan serta laporan historis lainnya. Variabel terikat dalam penelitian ini adalah profitabilitas (Y). Variabel bebas dalam penelitian ini adalah kecukupan modal ( $\left.\mathrm{X}_{1}\right)$, penyaluran kredit $\left(\mathrm{X}_{2}\right)$ dan ukuran perusahaan $\left(\mathrm{X}_{3}\right)$. Variabel moderasi dalam penelitian ini adalah risiko kredit (Z).

Menurut Taswan (2014:60) rumus perhitungan profitabilitas adalah sebagai berikut:

$$
\mathrm{ROA}=\frac{\text { Laba Bersih }}{\text { Total Aktiva }} \times 100 \%
$$

Menurut Taswan (2014:59) rumus untuk perhitungan CAR sebagai berikut:

$$
\mathrm{CAR}=\frac{\text { MODAL }}{\text { ATMR }} \times 100 \%
$$

Menurut Taswan (2014:61) rumus untuk perhitungan LDR adalah sebagai berikut:

$$
\text { LDR }=\frac{\text { Total Kredit yang diberikan }}{\text { Total Dana Pihak Ketiga }} \times 100 \%
$$

Menurut Jogiyanto (2007:282) rumus untuk perhitungan ukuran perusahaan sebagai berikut:

Ukuran Perusahaan $($ Size $)=$ LnTotalAktiva

Menurut Taswan (2014:59) rumus untuk perhitungan NPL sebagai berikut: 
A.A. Trisha Dewi Parashtiwi dan I Gusti Ayu Nyoman Budiasih. Pengaruh...

$$
\text { NPL }=\frac{\text { Kredit Bermasalah }}{\text { Total Kredit }} \times 100 \%
$$

Populasi yang digunakan dalam penelitian ini adalah seluruh perusahaan perbankan yang tercatat di Bursa Efek Indonesia pada periode 2013-2017. Populasi yang digunakan dalam penelitian ini adalah seluruh perusahaan perbankan yang tercatat di Bursa Efek Indonesia pada periode 2013-2017. Metode pengambilan sampel yang digunakan adalah non probability sampling dengan Teknik purposive sampling.

Penelitian ini menggunakan Teknik analisis data Moderated Regression Analysis. MRA adalah salah satu alat khusus dalam pengujian regresi linier berganda. Persamaan MRA dalam penelitian ini adalah sebagai berikut.

$Y=\alpha+\beta_{1} X_{1}+\beta_{2} X_{2}+\beta_{3} X_{3}+\beta_{4} Z+\beta_{5} X_{1} Z+\beta_{6} X_{2} Z+\beta_{7} X_{3} Z+\varepsilon$

Keterangan:

$\mathrm{Y} \quad=$ Variabel dependen

$\mathrm{X}_{1}, \mathrm{X}_{2}$, dan $\mathrm{X}_{3} \quad=$ Variabel independen

$\mathrm{Z} \quad=$ Variabel moderasi

$\alpha \quad=$ Konstanta

$\beta_{1}-\beta_{7} \quad=$ Koefisien regresi (nilai peningkatan ataupun penurunan)

$\mathrm{e}=$ Error

\section{HASIL DAN PEMBAHASAN}

Statistik deskriptif disajikan untuk memberikan informasi mengenai karakteristik variabel-variabel penelitian, yaitu jumlah sampel, nilai maksimum, nilai minimum, nilai rata-rata dan standar deviasi. Hasil statistik deskriptif penelitian ini dapat dilihat pada Tabel 2 sebagai berikut. 
Tabel 2.

Hasil Uji Statistik Deskriptif

\begin{tabular}{llllll}
\hline & N & \multicolumn{1}{c}{ Minimum } & \multicolumn{1}{c}{ Maximum } & \multicolumn{1}{c}{ Mean } & Std. Deviation \\
\hline CAR & 160 & 10.440 & 66.430 & 20.36231 & 6.552243 \\
LDR & 160 & 42.020 & 140.720 & 84.21063 & 13.863663 \\
SIZE & 160 & 13.660 & 20.840 & 17.41400 & 1.817072 \\
NPL & 160 & .000 & 8.540 & 2.26013 & 1.291499 \\
ROA & 160 & .130 & 3.900 & 1.28175 & .761521 \\
CAR_NPL & 160 & .000 & 305.578 & 44.69849 & 31.341104 \\
LDR_NPL & 160 & .000 & 694.644 & 193.58313 & 114.2947 \\
SIZE_NPL & 160 & .000 & 157.819 & 39.78059 & 23.230188 \\
\hline
\end{tabular}

Sumber: Data diolah, 2018

Berdasarkan hasil uji statistik deskriptif pada Tabel 2 dapat dijelaskan bahwa nilai rata-rata Return On Assets (ROA) sebesar 1.28175 yang memiliki arti bahwa total aktiva sebesar 1 rupiah maka akan menghasilkan laba bersih sebesar 1,28 rupiah dengan standar deviasi sebesar 0,761521 . Nilai minimum sebesar 0,13 persen terdapat pada perusahaan PT. Bank Bukopin tahun 2017 sedangkan nilai maksimum sebesar 3.9 persen terdapat pada perusahaan PT. Mestika Dharma tahun 2013.

Nilai rata-rata Capital Adequacy Ratio (CAR) sebesar 20,36231 yang memiliki arti bahwa aktiva tetimbang menurut risiko sebesar 1 rupiah maka akan dapat menutupi aktiva tetimbang menurut risiko tersebut dengan modal sebesar 20,36 rupiah dengan standar deviasi sebesar 6,552243. Nilai minimum sebesar 10,44 persen terdapat pada perusahaan PT. Bank Mayapada Internasional tahun 2014 sedangkan nilai maksimum sebesar 66,43 persen terdapat pada perusahaan PT. Bank Ina tahun 2017.

Nilai rata-rata Loan to Deposit Ratio (LDR) sebesar 84,21063 yang memiliki arti bahwa total dana pihak ketiga sebesar 1 rupiah maka akan dapat menyalurkan kredit sebesar 84,21 rupiah dengan standar deviasi sebesar 13.863663. Nilai minimum sebesar 42,02 persen terdapat pada perusahaan PT. 
A.A. Trisha Dewi Parashtiwi dan I Gusti Ayu Nyoman Budiasih. Pengaruh...

Bank Mitraniaga tahun 2017 sedangkan nilai maksimum sebesar 140,72 persen terdapat pada perusahaan PT. Bank Woori Saudara tahun 2013.

Nilai rata-rata ukuran perusahaan (SIZE) sebesar 17.41400 dengan standard deviasi sebesar 1.817072. Nilai minimum sebesar 13,66 persen terdapat pada perusahaan PT. Bank Dinar Indonesia tahun 2013 sedangkan nilai maksimum sebesar 20,84 persen terdapat pada perusahaan PT. Bank Mandiri (Persero) tahun 2017.

Nilai rata-rata Non Performing Loan (NPL) sebesar 2.26013 yang memiliki arti bahwa total kredit sebesar 1 rupiah maka akan memperoleh kredit bermasalah sebesar 2,26 rupiah dengan standar deviasi sebesar 1.291499. Nilai minimum sebesar 0,00 persen terdapat pada perusahaan PT. Bank Nationalnobu tahun 2014 dan 2016 sedangkan nilai maksimum sebesar 8,54 persen terdapat pada perusahaan PT. Bank Bukopin tahun 2017.

Interaksi Capital Adequacy Ratio (CAR) denganNon Performing Loan (NPL) memiliki nilai rata-rata sebesar 44.69849 dengan standar deviasi sebesar 31.341104. Nilai minimum sebesar 0,00 sedangkan nilai maksimum sebesar 305.578 .

Interaksi Loan to Deposit Ratio (LDR) denganNon Performing Loan (NPL) memiliki nilai rata-rata sebesar 193.58313 dengan standar deviasi sebesar 114.2947. Nilai minimum sebesar 0,00 sedangkan nilai maksimum sebesar 694.644.

Interaksi ukuran perusahaan (SIZE) dengan Non Performing Loan (NPL) memiliki nilai rata-rata sebesar 39.78059 dengan standar deviasi sebesar 
23.230188. Nilai minimum sebesar 0,00 sedangkan nilai maksimum sebesar 157.819.

Berikut adalah hasil dari uji Moderated Regression Analysis (MRA) yang disajikan dalam Tabel 3.

Tabel 3.

Hasil Moderated Regression Analysis (MRA)

\begin{tabular}{|c|c|c|c|c|c|c|}
\hline \multirow[b]{2}{*}{ Model } & & \multicolumn{2}{|c|}{$\begin{array}{l}\text { Unstandardized } \\
\text { Coefficients }\end{array}$} & $\begin{array}{c}\text { Standardized } \\
\text { Coefficients }\end{array}$ & \multirow[b]{2}{*}{$\mathbf{T}$} & \multirow[b]{2}{*}{ Sig } \\
\hline & & B & Std. Error & Beta & & \\
\hline 1 & (Constant) & -7.331 & 0.946 & & -7.747 & 0 \\
\hline & CAR & 0.025 & 0.012 & 0.212 & 2.101 & 0.037 \\
\hline & LDR & 0.018 & 0.006 & 0.334 & 3.058 & 0.003 \\
\hline & SIZE & 0.408 & 0.051 & 0.975 & 8.027 & 0 \\
\hline & NPL & 1.301 & 0.383 & 2.207 & 3.397 & 0.001 \\
\hline & CAR_NPL & -0.002 & 0.004 & -0.071 & -0.478 & 0.633 \\
\hline & LDR_NPL & -0.004 & 0.003 & -0.58 & -1.5 & 0.136 \\
\hline & SIZE_NPL & -0.067 & 0.021 & -2.041 & -3.12 & 0.002 \\
\hline $\mathrm{R}^{2}=.568$ & & & & & & \\
\hline F Hitung & $=28.576$ & & & & & \\
\hline Sig F & $=.000$ & & & & & \\
\hline
\end{tabular}

Berdasarkan Tabel 3 maka dapat disimpulkan hasil regresi sebagai berikut.

$Y=-7.331+0.025 X_{1}+0.018 X_{2}+0.408 X_{3}+1.301 Z-0.002 X_{1} . Z-0.004 X_{2} . Z-$ $0.067 \mathrm{X}_{3} . \mathrm{Z}$

Nilai konstanta sebesar $-7,331$ hal ini berarti bahwa bila asumsikan nilai CAR, LDR, NPL, SIZE, interaksi CAR pada NPL, interaksi LDR pada NPL dan interaksi SIZE pada NPL sama dengan nol maka perusahaan tidak memiliki profitabilitas sebesar 7,331 satuan.

Nilai koefisien regresi CAR sebesar 0,025 memiliki arti jika CAR meningkat sebesar 1 satuan, maka profitabilitas perusahaan akan meningkat sebesar 0,025 satuan dengan asumsi semua variabel independen lainnya konstan. 
A.A. Trisha Dewi Parashtiwi dan I Gusti Ayu Nyoman Budiasih. Pengaruh...

Nilai koefisien regresi LDR sebesar 0,018 memiliki arti jika LDR meningkat sebesar 1 satuan, maka profitabilitas perusahaan akan meningkat sebesar 0,018 satuan dengan asumsi semua variabel independen lainnya konstan.

Nilai koefisien regresi SIZE sebesar 0,408 memiliki arti jika SIZE meningkat sebesar 1 satuan, maka profitabilitas perusahaan akan meningkat sebesar 0,408 satuan dengan asumsi semua variabel independen lainnya konstan.

Nilai koefisien regresi NPL sebesar 1,301 memiliki arti jika NPL meningkat sebesar 1 satuan, maka profitabilitas perusahaan akan meningkat sebesar 1,301 satuan dengan asumsi semua variabel independen lainnya konstan.

Nilai koefisien regresi interaksi CAR pada NPL sebesar -0,002 memiliki arti jika interaksi CAR pada NPL meningkat sebesar 1 satuan, maka profitabilitas perusahaan akan menurun sebesar 0,002 satuan dengan asumsi semua variabel independen lainnya konstan.

Nilai koefisien regresi interaksi LDR pada NPL sebesar -0,004 memiliki arti jika interaksi LDR pada NPL meningkat sebesar 1 satuan, maka profitabilitas perusahaan akan menurun sebesar 0,004 satuan dengan asumsi semua variabel independen lainnya konstan.

Nilai koefisien regresi interaksi SIZE pada NPL sebesar -0,067 memiliki arti jika interaksi SIZE pada NPL meningkat sebesar 1 satuan, maka profitabilitas perusahaan akan menurun sebesar 0,067 satuan dengan asumsi semua variabel independen lainnya konstan.

Koefisien determinasi $\left(\mathrm{R}^{2}\right)$ diukur untuk mengetahui persentase pengaruh variabel independen pada perubahan variabel dependen. Koefisien determinasi 
pada model regresi dilihat dari nilai $\mathrm{R}^{2}$. Pada Tabel 4.6 nilai $\mathrm{R}^{2}$ sebesar 0,568 atau 56,8 persen. Hal ini berarti bahwa variabel profitabilitas perusahaan yang diproksikan denga ROA dapat dijelaskan sebesar 56,8 persen oleh variabel CAR, LDR, SIZE dan NPL sedangkan sisanya sebesar 43,2 persen dipengaruhi oleh variabel lain.

Uji kelayakan model (Uji F) digunakan untuk mengetahui apakah model regresi Moderated Regression Analysis (MRA) dalam penelitian ini layak digunakan atau tidak. Pada Tabel 3 nilai $F$ hitung sebesar 28,576 dengan signifikansi 0,000. Nilai signifikansi tesebut lebih kecil dari level signifikansi 0,05. Jadi dapat disimpulkan

Hasil pengujian menggunakan regresi moderasi menunjukkan bahwa koefisien regresi kecukupan modal memiliki nilai sebesar 0,025 dengan tingkat signifkansi sebesar 0,037 yang berarti lebih kecil dari $\alpha=0,05$ yang artinya sesuai dengan hipotesis yang diharapkan sehingga $\mathrm{H}_{1}$ diterima. Hal ini menunjukkan bahwa kecukupan modal berpengaruh positif signifikan pada profitabilitas perusahaan.

Peranan modal sangat penting, dimana kegiatan operasional bank dapat berjalan dengan lancar apabila memiliki modal yang cukup, sehingga pada saat masa-masa kritis bank tetap aman karena memiliki cadangan modal (Hendra, 2016). Bank yang memiliki tingkat permodalan yang tinggi dinilai akan mampu menjaga kemungkinan dari timbulnya risiko kerugian kegiatan usahanya sehingga kinerja bank juga meningkat. Permodalan tinggi yang dimiliki oleh bank juga dinilai mampu dalam hal kelancaran operasional yang juga akan mampu 
A.A. Trisha Dewi Parashtiwi dan I Gusti Ayu Nyoman Budiasih. Pengaruh...

menambah kepercayaan dari nasabah untuk menyimpan danaya maupun menggunakan jasa-jasa dari perusahan perbankan, karena dari kepercayaan tersebut pendapatan bank akan meningkat sehingga berdampak pada profitabilitas yang akan meningkat. Maka semakin tinggi permodalan yang dimiliki akan berdampak pada profitabilitas yang semakin meningkat. Secara teori bank yang mempunyai CAR di atas 8 persen sangat baik karena bank mampu menanggung adanya risiko yang timbul.

Penelitian ini didukung dengan hasil penelitian sebelumnya yang dilakukan oleh Primadewi (2015), Pudja (2014) dan Suardita (2015) yang menyatakan bahwa kecukupan modal memiliki pengaruh positif dan signifikan pada profitabilitas.

Hasil pengujian menggunakan regresi moderasi menunjukkan bahwa koefisien regresi tingkat penyaluran kredit memiliki nilai sebesar 0,018 dengan tingkat signifkansi sebesar 0,003 yang berarti lebih kecil dari $\alpha=0,05$ yang artinya sesuai dengan hipotesis yang diharapkan sehingga $\mathrm{H}_{2}$ diterima. Hal ini menunjukkan bahwa tingkat penyaluran kredit berpengaruh positif signifikan pada profitabilitas perusahaan.

Penyaluran kredit berpengaruh positif pada profitabilitas yang artinya semakin tinggi bank menyalurkan kredit maka profitabilitas akan semakin meningkat. Penyaluran kredit dapat meningkatkan profitabilitas dengan asumsi tidak adanya risiko kredit yang timbulkan. Sehingga semakin besar jumlah kredit yang disalurkan kepada nasabah maka jumlah dana yang menganggur akan semakin berkurang dan pendapatan bunga yang diperoleh semakin meningkat. 
Semakin tinggi rasio LDR yang diberikan maka profitabilitas perbankan akan semakin tinggi (Setiadi, 2010). Ini berarti bahwa semakin besar bank menyalurkan kreditnya maka perolehan laba akan semakin meningkat dari adanya penciptaan kredit. Penyaluran kredit yang baik adalah penyaluran kredit yang tetap memperhatikan kelikuiditasan bank tersebut agar kelangsungan dan profitabilitas bank dapat terjaga.

Menurut Eprima (2015) besarnya jumlah kredit yang disalurkan oleh bank maka akan menentukan keuntungan yang akan diperoleh oleh bank. Hasil dari penelitian ini sesuai dengan hasil penelitian sebelumnya yang dilakukan oleh Agustiningrum (2013), Farida (2015), Trisna (2017) dan Novita (2016) yang menyatakan bahwa penyaluran kredit berpengaruh positif dan signifikan pada profitabilitas.

Hasil pengujian menggunakan regresi moderasi menunjukkan bahwa koefisien regresi ukuran perusahaan memiliki nilai sebesar 0,408 dengan tingkat signifkansi sebesar 0,000 yang berarti lebih kecil dari $\alpha=0,05$ yang artinya sesuai dengan hipotesis yang diharapkan sehingga $\mathrm{H}_{3}$ diterima. Hal ini menunjukkan bahwa ukuran perusahaan berpengaruh positif signifkan pada profitabilitas perusahaan.

Perusahaan yang memiliki ukuran perusahaan yang besar dan mapan akan mudah memiliki akses masuk ke pasar modal. Karena kemudahan untuk berhubungan dengan pasar modal maka berarti fleksibilitas lebih besar dan tingkat kepercayaan investor juga lebih besar karena mempunyai kinerja operasional yang lebih besar. Perusahaan besar juga mampu menarik minat investor yang lebih 
A.A. Trisha Dewi Parashtiwi dan I Gusti Ayu Nyoman Budiasih. Pengaruh...

besar dibandingkan dengan perusahaan kecil, karena mempunyai fleksibilitas penempatan investasi yang lebih baik. Perusahaan besar relatif lebih stabil dan lebih mampu menghasilkan laba dibandingkan dengan perusahaan kecil, dan perusahaan kecil pada umumnya mempunyai tingkat efisiensi yang rendah dan leverage finansial yang tinggi.

Menurut Sudarmadji (2007), perusahaan besar yang memiliki sumber daya yang besar pasti akan melakukan pengungkapan lebih luas dan dinilai mampu membiayai penyediaan informasi untuk keperluan internal. Informasi tersebut sekaligus dapat dijadikan bahan untuk keperluan pengungkapan informasi kepada pihak eksternal seperti investor dan kreditor, sehingga tidak memerlukan tambahan biaya yang besar untuk melakukan pengungkapan lebih luas. Dengan demikian, perusahaan yang besar mempunyai biaya produksi informasi yang lebih rendah daripada perusahaan kecil. Penelitian ini sesuai dengan hasil penelitian sebelumnya yang dilakukan oleh Koriawan (2014), Winahyu (2018), Daniel (2017) dan Ambarwati dkk. (2015) yang menyatakan bahwa ukuran perusahaan berpengaruh positif dan signifikan pada profitabilitas.

Hasil pengujian dengan menggunakan regresi moderasi menunjukkan bahwa koefisien regresi interaksi variabel kecukupan modal dengan risiko kredit menunjukkan nilai koefisien sebesar negatif 0,002 dengan nilai signifikansi sebesar 0,633 yang memiliki arti lebih besar dari taraf nyata 0,05 sehingga $\mathrm{H}_{4}$ ditolak. Hal ini menunjukkan bahwa risiko kredit tidak mampu memperlemah pengaruh kecukupan modal pada profitabilitas perusahaan. 
Risiko kredit memperlemah hubungan kecukupan modal pada profitabilitas perusahaan karena arah koefisiennya negatif tetapi untuk tingkat signifikansinya tidak tepenuhi. Apabila risiko kredit yang dialami oleh bank rendah maka tidak akan berdampak pada ativitas permodalan bank. Risiko kredit pada penelitian ini masih memiliki nilai rata-rata dibawah standar yang ditetapkan oleh Bank Indonesia yang artinya risiko kredit tidak menganggu tingkat permodalan yang dimiliki oleh bank.

Menurut Purba (2018) dengan adanya risiko kredit yang rendah maka bank akan dapat mengoptimalkan modal yang ada sehingga akan berpengaruh pada peningkatan profitabilitas. Hasil penelitian ini sesuai dengan penelitian yang dilakukan oleh Purba (2018) dan Warnayanti (2018) yang menyatakan bahwa risiko kredit tidak mampu memoderasi pengaruh kecukupan modal pada profitabilitas.

Hasil pengujian dengan menggunakan regresi moderasi menunjukkan bahwa koefisien regresi interaksi variabel penyaluran kredit dengan risiko kredit menunjukkan nilai koefisien sebesar negatif 0,004 dengan nilai signifikansi sebesar 0,136 yang memiliki arti lebih besar dari taraf nyata 0,05 sehingga $\mathrm{H}_{5}$ ditolak. Hal ini menunjukkan bahwa risiko kredit tidak mampu memperlemah pengaruh tingkat penyaluran kredit pada profitabilitas perusahaan.

Teori kontingensi bertolak belakang dalam penelitian ini karena risiko kredit tidak terbukti dapat mempengaruhi kecukupan modal yang berdampak pada penurunan profitabilitas. Rata - rata NPL bank pada saat periode 2013-2017 mencapai sebesar 2,26 persen yang berada pada batas bawah maksimum NPL 
A.A. Trisha Dewi Parashtiwi dan I Gusti Ayu Nyoman Budiasih. Pengaruh...

yang disyaratkan oleh Bank Indonesia sebesar 5 persen. Nilai NPL yang masih berada dibawah batas maksimum tidak berdampak pada peningkatan atau penurunan kecukupan modal bak dan tidak berdampak pada profitabilitas bank.

Hasil pengujian dengan menggunakan regresi moderasi menunjukkan bahwa koefisien regresi interaksi variabel ukuran perusahaan dengan risiko kredit menunjukkan nilai koefisien sebesar negatif 0,067 dengan nilai signifikansi sebesar 0,002 yang memiliki arti lebih kecil dari taraf nyata 0,05 sehingga $\mathrm{H}_{6}$ diterima. Hal ini menunjukkan bahwa risiko kredit mampu memperlemah pengaruh ukuran perusahaan pada profitabilitas perusahaan.

Kalopo, dkk. (2012) menyatakan bahwa diantara risiko-risiko yang dihadapi oleh bank, risiko kredit memiliki peran yang sangat penting pada profitabilitas lembaga perbankan, karena dapat mendatangkan kerugian dari pendapatan bank berupa pinjaman yang menghasilkan bunga kredit. Penelitian ini sesuai dengan penelitian sebelumnya yang dilakukan oleh Fanani dan Alvaribi (2013) dan Purba (2018) yang menyatakan bahwa risiko kredit mampu meperlemah pengaruh ukuran perusahaan pada profitabilitas.

\section{SIMPULAN}

Variabel kecukupan modal berpengaruh positif signifikan pada profitabilitas perusahaan perbankan periode 2013-2017. Hal ini berarti jika semakin besar kecukupan modal yang dimiliki maka profitabilitas akan meningkat.

Variabel penyaluran kredit berpengaruh positif signifikan pada profitabilitas perusahaan perbankan periode 2013-2017. Hal ini berarti jika semakin besar 
tingkat penyaluran kredit maka profitabilitas akan meningkat dengan adanya pendapatan bunga.

Variabel ukuran perusahaan berpengaruh positif signifikan pada profitabilitas perusahaan perbankan periode 2013-2017. Hal ini berarti jika semakin besar suatu ukuran perusahaan maka profitabilitas yang dicapai akan cenderung meningkat.

Risiko kredit tidak mampu memperlemah pengaruh kecukupan modal pada profitabilitas perusahaan perbankan perbankan periode 2013-2017. Risiko kredit tidak mampu memperlemah pengaruh penyaluran kredit pada profitabilitas perusahaan perbankan perbankan periode 2013-2017. Risiko kredit mampu memperlemah pengaruh ukuran perusahaan pada profitabilitas perusahaan perbankan perbankan periode 2013-2017. Koefisien regresi yang bertanda negatif menunjukkan bahwa apabila risiko kredit tinggi akan mampu menurunkan profitabilitas. Risiko kredit memoderasi negatif hubungan antara ukuran perusahaan pada profitabilitas perusahaan.

Saran bagi perusahaan perbankan sebaiknya perlu menjaga rasio keuangan CAR, LDR dan NPL agar tetap sesuai dengan peraturan yang telah ditetapkan Bank Indonesia. Perbankan juga harus mampu menjaga sistemnya agar NPL dapat ditekan, karena apabila NPL menurun maka akan berdampak pada ROA yang semakin meningkat. Sebaliknya apabila dalam suatu perbankan NPL nya meningkat maka ROA menjadi semakin menurun. Hal ini dapat mengganggu kestabilan permodalan bank maupun aktivitas dari penyaluran kredit. Bank yang terdaftar di BEI untuk pemanfaatan modalnya lebih dititikberatkan pada aktiva 
A.A. Trisha Dewi Parashtiwi dan I Gusti Ayu Nyoman Budiasih. Pengaruh...

dalam bentuk kredit yang disalurkan. Bagi peneliti selanjutnya bisa menggunakan perhitungan untuk menghitung ROA dengan cara membandingkan laba bersih dengan rata-rata total aset yang dimiliki oleh perusahaan tersebut.

\section{REFERENSI}

Adawiyah, A. Z. (2017). Pengaruh Modal, Aset dan Ukuran Perusahaan Terhadap Profitabilitas Perbankan. Jurnal Ilmu Dan Riset Manajemen, 6(1).

Agustiningrum, R. (2013). Analisis pengaruh CAR, NPL, dan LDR terhadap Profitabilitas pada Perusahaan Perbankan. E-Jurnal Manajemen Universitas Udayana.

Akhtar, M., Ali, K., \& Sadaqat, S. (2011). Factors Influencing the Profitability of Islamic Banks of Pakistan. International Research Journal of Finance and Economics., 66(66), 1-8.

Ali, M. (2004). Aset Liability Management: Menyiasati Risiko Pasar dan Risiko Operasional. Jakarta: PT. Gramedia.

Ambarwati, S., Yuniarta, G. A., \& Sinarwati, N. K. (2015). Pengaruh Modal Kerja, Likuiditas, Aktivitas dan Ukuran Perusahaan Terhadap Profitabilitas Pada Perusahaan Manufaktur yang Terdaftar di Bursa Efek Indonesia. EJournal S1 Ak Universitas Pendidikan Ganesha, 3(1).

Daniel, W. (2017). Pengaruh Ukuran Perusahaan, Suku Bunga dan Struktur Modal Terhadap Profitabilitas. E-Jurnal Manajemen Unud, 6(12), 69136931.

Eprima, Luh Dewi, N. T. H. dan L. G. E. S. (2015). Analisis Pengaruh NIM , BOPO , LDR , DAN NPL Terhadap Profitabilitas (Studi Kasus Pada Bank Umum Swasta Nasional Yang Terdaftar Pada Bursa Efek Indonesia Periode 2009-2013). E-Journal S1 Akuntansi Universitas Pendidikan Ganesha, 3(1), $58-72$.

Fanani, Z., Nur, M., \& Alvaribi, Q. (2013). Faktor - faktor Penentu Risiko Kredit. Jurnal Kajian Ekonomi Dan Bisnis Islam, 6(2), 293-317.

Farhan, M., Sattar, A., Hussain, A., \& Fareeha, C. (2012). Economic Determinants of Non-Performing Loans: Perception of Pakistani Bankers. European Journal of Business and Management, 4(19), 87-100.

Farida, N. (2015). Analisis Pengaruh Penyaluran Kredit Terhadap Profitabilitas 
yang di Moderasi Rasio Non Perfoming Loan (NPL). Artikel Ilmiah, 1-15.

Haneef, S., Rana, M. A., \& Karim, Y. (2012). Impact of Risk Management on Non-Performing Loans and Profitability of Banking Sector of Pakistan. International Journal of Business and Social Science, 3(7), 307-315.

Hariputri, P. U. (2018). Pengaruh Pertumbuhan Kredit Terhadap Profitabilitas dengan Tingkat Kolektibilitas Kredit Sebagai Pemoderasi Pada Lembaga Perkreditan Desa. E-Jurnal Akuntansi Universitas Udayana, 24(1), 399-421.

Hariyanto, L. (2014). Pengaruh Family Control, Firm Risk, Firm Size dan Firm Age Terhadap Profitabilitas Dan Nilai Perusahaan Pada Sektor Keuangan. Business Accountitng Review, 2(1), 141-150.

Hendra, E. S. (2016). Pengaruh Kecukupan Modal, Risiko Kredit dan Biaya Operasional Terhadap Profitabilitas Bank. Pengaruh Kecukupan Modal, Risiko Kredit Dan Biaya Operasional Terhadap Profitabilitas Bank., 14(3), 2363-2378.

Indrayani, P. A., Yudiaatmaja, F., \& Suwendra, I. W. (2016). Pengaruh Non Perfoming Loan (NPL), Loan To Deposit Ratio (LDR) Dan Net Interest Margin (NIM) Terhadap Return on Asset (ROA) Pada Bank Umum Yang Terdaftar Di Bursa Efek Indonesia Tahun 2014. E-Journal Bisma Universitas Pendidikan Ganesha Jurusan Manajemen, 4(1), 28-47.

Jogiyanto, H. (2007). Teori Portofolio dan Analisis Investasi. Yogyakarta: BPFE.

Kalopo, T Funso, Kolade, Ayeni R., and Ojo, O. M. (2012). Credit Risk and Commercial Bank Performance in Nigeria: A Panel Model Approach. Australian Journal of Bussiness Management Research, 2(02), 31-38.

Kasmir. (2012). Manajemen Perbankan Edisi Keenam. Jakarta: PT. Raja Grafindo Persada.

Koriawan, M. U. P. (2014). Pengaruh Ukuran Perusahaan, Struktur Finansial dan Pertumbuhan Jumlah Nasabah Kredit Pada Profitabilitas. E-Jurnal Akuntansi Universitas Udayana, 9(3), 608-616.

Kosmidou, K. (2008). The determinants of banks'profits in Greece during the period of EU financial integration. Managerial Finance, 34(3), 146-159.

Kumala, P. A. S. (2015). Pengaruh Capital Adequacy Ratio, Bank Size dan BI Rate Terhadap Risiko Kredit (NPL) Pada Perusahaan Perbankan. E-Jurnal Manajemen Unud, 4(8), 2228-2242.

Madjid, N. C. (2013). Pengaruh Dana Pihak Ketiga (DPK) dan Likuiditas (LDR) 
A.A. Trisha Dewi Parashtiwi dan I Gusti Ayu Nyoman Budiasih. Pengaruh...

Terhadap Return On Asset (ROA) Pada Perusahaan Perbankan yang Terdaftar di BEI. Online Journal Fakultas Ekonomi Universtas Negeri Gorontal.

Mario, F. (2015). Pengaruh BOPO, LDR, NPM dan Bulletin Studi Ekonomi Ukuran Perusahaan Pada Perusahaan Perbankan yang Listed di Bursa Efek Indonesia. Universitas Pandanaran.

Markusiwati, N. K. L. A. (2007). Evakuasi Pengaruh CAMEL Terhadap Kinerja Keuangan. Bulletin Studi Ekonomi, 2(1).

Novita, N. P. E. (2016). Kualitas Kredit Sebagai Pemoderasi Tingkat Penyaluran Kredit dan BOPO Pada Profitabilitas. E-Jurnal Akuntansi Universitas Udayana, 15(1), 784-798.

Oktaviani, A., \& Yusuf, M. (2014). Pengaruh Jumlah Kredit yang Disalurkan Terhadap Profitabilitas Perbankan dengan Moderasi Resiko Kredit. Jurnal Manajemen Dan Akuntansi PRESTASI, 13(2), 30-45.

Prasanjaya, A. A. Y. (2013). Analisis Pengaruh CAR, BOPO, LDR dan Ukuran Perusahaan Terhadap Profitabilitas pada Bank yang Terdaftar di BEI. EJurnal Akuntansi Universitas Udayana, 4(1), 230-245.

Primadewi, C. I. D. R. dan I. D. G. D. S. (2015). Pengaruh Capital Adequacy Ratio, Non Performing Loan dan Dana Pihak Ketiga Pada Profitabilitas. EJurnal Akuntansi Universitas Udayana, 13(2), 489-498.

Pudja, N. M. A. D. (2014). Pengaruh Perputaran Kredit, Kecukupan Modal, dan Jumlah Nasabah Pada Profitabilitas. E-Jurnal Akuntansi Universitas Udayana, 8(3), 584-597.

Purba, A. G. (2018). Pengaruh Kecukupan Modal , Struktur Modal dan Ukuran Perusahaan Pada Profitabilitas dengan Risiko Kredit Sebagai Pemoderasi. EJurnal AKuntansi Universitas Udayana, 23, 1008-1037.

Ratnawati, Kusuma., Esther Novelina Hutagalung, dan D. (2013). Analisa Rasio Keuangan terhadap Kinerja Bank Umum di Indonesia. Jurnal Aplikasi Manajemen, 11(1), 122-130.

Rengasamy, D. (2014). Impact of Loan Deposit Ratio (LDR) on Profitability: Panel Evidence from Commercial Banks in Malaysia. Paper ID: MF498.

Riyadi, S. (2006). Banking Assets and Liability Management Edisi Ketiga. Jakarta: Lembaga Penerbitan Fakultas Ekonomi Universitas Indonesia.

Sartono, R. A. (2014). Manajemen Keuangan: Teori dan Aplikasi. Yogyakarta: 
BPFE.

Setiadi, P. B. (2010). Analisis Hubungan Spread of Interest Rate, Fee Based Income dan Loan to Deposit Ratio dengan Return On Assets pada Perbankan di Jawa Timur. Jurnal Mitra Ekonomi Dan Manajemen Bisnis, 1(1).

Shamsuddoha, Mohammad and Alamgir, M. (2004). Loyalty and Satisfaction Construct in Retail Banking - An Empirical Study on Bank Customers. The Chittagong University Journal of Bussiness Administration, 19.

Singh, A. (2015). Effect of Credit Risk Management on Private and Public Sector Banks in India. International Journal of Academic Research in Business and Social Sciences Mewar University, 5(1), 97-106.

Suardita, I. W. dan I. G. A. M. D. P. (2015). Pengaruh Kecukupan Modal Dan Penyaluran Kredit Pada Profitabilitas Dengan Pemoderasi Risiko Kredit. EJurnal Akuntansi Universitas Udayana, 11(2), 426-440.

Sudarmadji, M. dan S. (2007). Pengaruh Ukuran Perusahaan, Profitabilitas, Leverage, dan Tipe Kepemilikan Terhadap Voluntary Disclosure Laporan Keuangan Tahunan. Procedding PESAT, 2, 21-22.

Taswan. (2014). Akuntansi Perbankan Transaksi dalam Valuta Rupiah. Yogyakarta: UPP STIM YKPN.

Trisna, A. A. A. (2017). Kualitas Kredit Sebagai Pemoderasi Pengaruh Tingkat Penyaluran Kredit dan Dana Pihak Ketiga Pada Profitabilitas. E-Jurnal Akuntansi Universitas Udayana, 19(3), 2090-2117.

Utami, I. A. T. I. (2016). Non Performing Loan Sebagai Pemoderasi Pengaruh Kredit Yang Disalurkan Pada Profitabilitas. E-Jurnal Akuntansi Universitas Udayana, 15(3), 2107-2133.

Velnampy, T dan Nimalathasan, B. (2010). Firm Size and Profitability : A Study of Listed Manufacturing Firms in Sri Lanka. Global Journal of Management and Busniss Research, 10(2), 96-100.

Wantera, N. L. K. P. S. M. dan I. M. M. (2015). Pengaruh Penerapan Corporate Governance, DPK, CAR dan NPL terhadap Profitabilitas Bank. E-Jurnal Akuntansi Universitas Udayana, 12(2), 154-171.

Warnayanti, N. K. A. (2018). Peran Risiko Kredit Dalam Memoderasi Pengaruh Kecukupan Modal, Penyaluran Kredit Dan BOPO Terhadap Profitabilitas. EJurnal Manajemen Unud, 7(1), 105-133.

Wibisono, K. (2013). Analisis Pengaruh CAR, NPL, NIM dan LDR Terhadap 
A.A. Trisha Dewi Parashtiwi dan I Gusti Ayu Nyoman Budiasih. Pengaruh...

ROA Pada Bank Umum Swasta Nasional di Indonesia. Jurnal Ekonomi Daerah, 1(1), 1-12.

Winahyu, N. W. R. (2018). Intellectual Capital sebagai Pemoderasi Pengaruh Debt to Equity Ratio dan Ukuran Perusahaan pada Profitabilitas. E-Jurnal Akuntansi Universitas Udayana, 23(1), 734-760.

Yunita, N. A. dan M. Y. (2016). Pengaruh Kecukupan Modal dan Penyisihan Penghapusan Aktiva Produktif Terhadap Profitabilitas dengan Rasio Kredit Bermasalah Sebagai Variabel Moderasi Pada Perusahaan Perbankan. Jurnal Akuntansi Dan Keuangan, 5(1), 73-87. 